\title{
Morphological Gill Analysis of Fish Species Prochilodus Lineatus after Exposure to Pollutants
}

Bruno Fiorelini Pereira ${ }^{1 *}$, Rebeca Mamede da Silva Alves ${ }^{1}$, Dimítrius Leonardo Pitol², José Algusto Senhorini ${ }^{3}$ Rita de Cássia Gimenes de Alcântara Rocha ${ }^{3}$ and Flavio Henrique Caetano ${ }^{1}$

'Universidade Estadual Paulista "Júlio de Mesquita Filho" UNESP, Instituto de Biociências - Campus de Rio Claro, SP, Brazil

${ }^{2}$ Faculdade de Odontologia - USP - Ribeirão Preto, SP, Brazil

${ }^{3}$ ICMBio/CEPTA - Pirassununga, SP, Brazil

\begin{abstract}
The gill is the respiratory organ in fish but it is also responsible for ion exchange with the environment, what makes it highly susceptible to pollutants. This study aimed to identify possible histological and histochemical changes in the gill of fish species Prochilodus lineatus exposed to biodegradable detergents and water from an urban lake. The results showed not only morphological alterations such as lamellae fusion and hyperplasia, as well as increase in collagen, changes in nuclear volume and increase in the number of chloride and mucous cells. These results show that common pollutants dumped into rivers and urban lakes can cause several changes in the respiratory organ, possibly leading to a metabolic deficit in fish.
\end{abstract}

Keywords: Gill; Prochilodus lineatus; Pollutants; Chloride cells; Mucous cells

\section{Introduction}

According to Pough et al. [1], most of aquatic vertebrates have gills, which are specialized structures for gas exchange, placed in the pharyngeal pouches in fish. According to Pough et al. [1], the water flow is usually unidirectional, entering through the mouth, passing over the gills and exiting through the operculum. The vascular arrangement of gills maximizes the exchange of oxygen; each gill filament has two vessels: the afferent vessel, which extends from the gill arch to the tip of the filament, and the efferent vessel, which returns blood to the gill arch [1]. The gills, which should be permeable to oxygen and carbon dioxide, are also permeable to water and as a result, most of the movements of water and ions occur through the gill surface.

The gill epithelium coats the gill arch, rakers, filaments and interlamellar regions, it is stratified and composed of several cell types (pavement cells, mucus-secreting cells, chloride cells and nondifferentiated supporting cells), as well as taste buds [2]. The chloride cells are large, scattered on the lamellar surface, rich in mitochondria and act in the transportation of active ions [2,3]. Moreover, due to a large number of mitochondria in these cells, they are also known as mitochondria-rich cells or MRC [4].

According to Evans [4], since the beginning of physiological studies, numerous articles have demonstrated that chloride cells may express active Na-K-ATPase in a variety of teleosts. As reported by Perry [3], several studies have suggested that chloride cells are active sites for the regulation of ion transport in marine and freshwater fish, especially in marine fish, in which ion transportation can account for a substantial portion of energy budget, due to the hydrolysis of ATP by the various ion-transport ATPases. Under unfavorable ionic conditions or in contact with toxic agents, the chloride cells proliferate in the filaments and gill lamellar surface [3]. According to Perry and Walsh [5], these cells have higher metabolic rate than the others found in gill, and the metabolic rate of the rest of the organ directly affects the population of chloride cells, which may generate their proliferation.

According to Nilsson [6], if on one hand a large surface facilitates gas exchange, on the other hand, it can cause several problems, including energetically unfavorable fluxes of water and ions. The author continues stating that as a result, fish appear to have a respiratory surface area matched to their oxygen demands.

When faced with changes in the need for oxygen uptake, for example through altered physical activity or altered ambient oxygen levels, fish have long been known to make two different adjustments: 1 ) change the water flow over the gills or 2) change the blood flow inside the gills [6]. Moreover, it has recently become clear that at least some teleosts have a third option: reversibly remodel the gill morphology [6]. In this context, the analysis of morphological changes is an efficient tool for diagnosing and identifying the physiological consequences of sublethal contamination [7].

This article aimed to identify the effects of urban pollutants in the fish species Prochilodus lineatus, which was chosen because its importance as a neotropical sensible specie and as a food resource.

\section{Material and Methods}

Individuals of the fish species Prochilodus lineatus were used in the present study, divided into three groups of 10 individuals each and each group was housed in a polyethylene box of 500 liters. The animals were fed with the same diet used at CEPTA - Chico Mendes Institute, location where the animals were collected. Temperature and oxygen levels were controlled by a system of recirculated water in each box to make sure only the water remained as a difference between the groups. The control group (referred as control) was exposed to provenly pure water from the well of UNESP - Rio Claro - SP. The second group

*Corresponding author: Bruno Fiorelini Pereira, Universidade Estadual Paulista UNESP - Campus de Rio Claro Av. 24A, 1515, Bela Vista, Rio Claro, São Paulo, 13506900, Brazil, E-mail: brunofp22@hotmail.com

Received November 07, 2011; Accepted March 03, 2012; Published March 05, 2012

Citation: Pereira BF, da Silva Alves RM, Pitol DL, Senhorini JA, de Alcântara Rocha RCG, et al. (2012) Morphological Gill Analysis of Fish Species Prochilodus Lineatus after Exposure to Pollutants. J Environment Analytic Toxicol 2:130. doi:10.4172/2161-0525.1000130

Copyright: (C) 2012 Pereira BF, et al. This is an open-access article distributed under the terms of the Creative Commons Attribution License, which permits unrestricted use, distribution, and reproduction in any medium, provided the original author and source are credited. 
Citation: Pereira BF, da Silva Alves RM, Pitol DL, Senhorini JA, de Alcântara Rocha RCG, et al. (2012) Morphological Gill Analysis of Fish Species Prochilodus Lineatus after Exposure to Pollutants. J Environment Analytic Toxicol 2:130. doi:10.4172/2161-0525.1000130
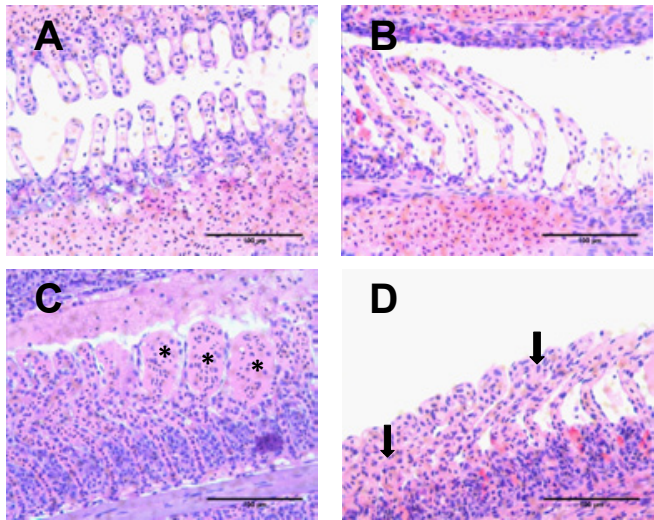

D
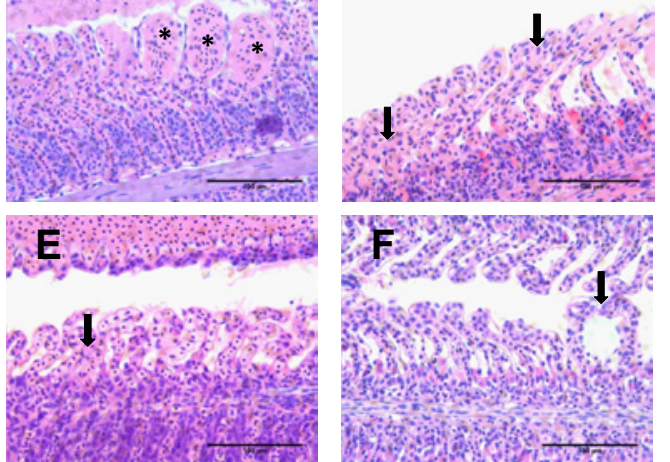

Figure 1: $A$ and $B$ - Aspect of the gill of the control group after 7 and 20 days of experiment respectively stained with $\mathrm{H}-\mathrm{E}$. C and $\mathrm{D}-$ Aspect of the gill of the detergent group after 7 and 20 days of experiment respectively stained with $\mathrm{H}-\mathrm{E}$. E and $\mathrm{F}$ - Aspect of the gill of the Blue Lake group after 7 and 20 days of experiment respectively stained with H-E. Notice the lamellar fusion (arrows) and hyperplasia (asterisk).
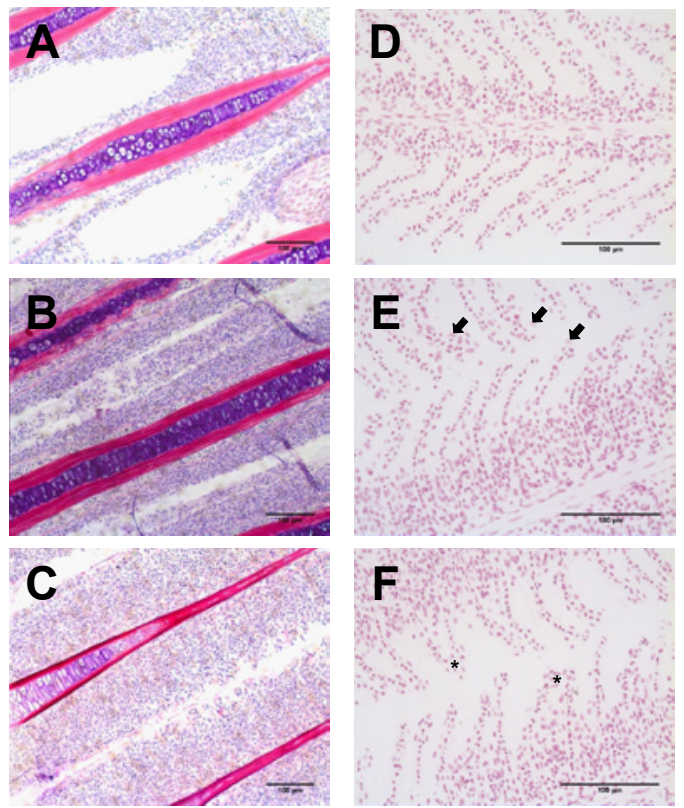

Figure 2: A - Aspect of the gill of the control group after 7 and 20 days of experiment stained with Picrocirius Red. B - Aspect of the gill of the detergent group after 20 days of experiment stained with Picrocirius Red. C- Aspect of the gill of the Blue Lake group after 7 and 20 days of experiment stained with Picrocirius Red. Notice an increase in the reaction in the detergent group, which represents deposition of more collagen in the gill. D - Aspect of the gill of the control group after 7 and 20 days of experiment stained with Feulgen. $E$ - Aspect of the gill of the detergent group after 7 and 20 days of experiment stained with Feulgen. F- Aspect of the gill of the Blue Lake group after 7 and 20 days of experiment stained with Feulgen. Notice an increase of nucleus size (arrows) and disorganization of the nucleus in the lamellar fusion area (asterisk). (referred as Blue Lake) was exposed to water of the lake "Lago Azul", located in Rio Claro - SP - Brazil. The third group (referred as detergent) was exposed to a dilution in the proportion of 1:1,000,000 of a mixture of biodegradable detergents from various brands, that have as in common the compound linear alkylbenzene sulfonates (LAS).

Few studies deal with the toxicity values of biodegradable detergents, and according to Roy [8], LD50 values for various groups of fishes range from $7 \mathrm{ppm}$ to $22.5 \mathrm{ppm}$. In such study, Roy [8] used a dilution of $1 \mathrm{ppm}$ in order to detect histological changes in very low levels of pollutant agents, considering that it is already expected that changes occur in higher levels and that dilutions of detergent in rivers should not exceed this value.

The analyzed materials were collected after the exposure periods of one week and twenty days. Before sacrifice, which was accomplished to collect the organs, the animals were anesthetized with benzocaine solution $(0.1 \mathrm{~g}$ benzocaine in $1 \mathrm{~mL}$ of ethyl alcohol per $100 \mathrm{~mL}$ of water) to minimize animal suffering during the process of dissection. The gills of 6 animals of each group were fixed in aqueous Bouin and prepared for historesin techniques with reactions in HE, PAS, Picrocirus Red, and Feulgen, and fixed in neutral formalin for Von Kossa technique.

The mucous and chloride cells were counted among 10 secondary lamellae and the count was repeated five times in each individual on each group. The results were submitted to the normality test of Shapiro - Wilk and the difference between the groups was analyzed with Kruskal-Wallis/Dunn, in the software Biostat 5.0.

To validate the experiment, all the protocols were performed in duplicate.

\section{Results}

Analysis showed secondary lamellae fusion and changes in gill morphology on individuals exposed to polluted environments, both in the detergent group and in the Blue Lake group throughout the experiment (Figure 1).

The technique of Picrosirius Red showed that only the detergent group exhibited increase in the amount of collagen around the cartilage found in the primary lamella, after twenty days of experiment (Figure 2A).

The slides submitted to the Feulgen reaction showed increase in the nucleus size of epithelial cells, which are found at the edges of hypertrophied secondary lamellae, both in the detergent and in the Blue Lake group (Figure 2B).

In order to analyze chloride and mucous cells (Figure 3), a cell count was necessary. In Von Kossa technique [9], it was observed
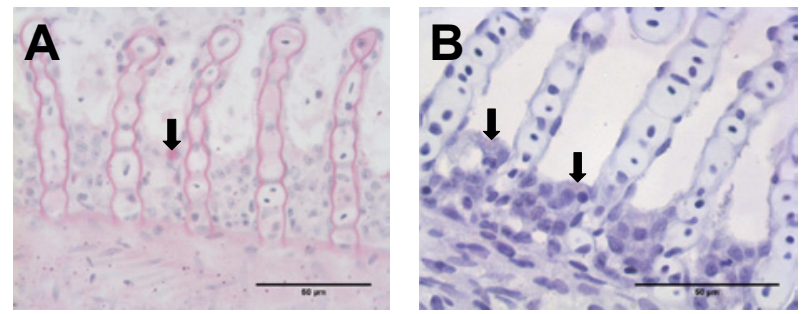

Figure 3: A - A mucous cell (arrow) in the gill evidenced by the PAS technique. B - Chloride cells (arrows) evidenced by the Von Kossa technique. 


\begin{tabular}{|c|c|c|c|c|c|c|c|c|c|c|}
\hline & \multicolumn{2}{|c|}{ Control } & \multicolumn{4}{|c|}{ Detergent } & \multicolumn{4}{|c|}{ Blue Lake } \\
\hline & \multirow{2}{*}{7 days } & \multirow{2}{*}{20 days } & \multicolumn{2}{|l|}{7 days } & \multicolumn{2}{|l|}{20 days } & \multicolumn{2}{|l|}{7 days } & \multicolumn{2}{|l|}{20 days } \\
\hline & & & Average & $p$ & Average & $p$ & Average & $p$ & Average & $p$ \\
\hline Mucous cells & 7,0 (SD-0,8) & 4,8 (SD-0,7) & $9,6(\mathrm{SD}-0,5)$ & $>0,01$ & $8,8(\mathrm{SD}-0,9)$ & $>0,01$ & 9,0 (SD-0,8) & $>0,01$ & $8,6(\mathrm{SD}-0,5)$ & $>0,01$ \\
\hline Chloride cells & $10,8(S D-1,4)$ & $10,1(1,2)$ & 11,8 (SD-1,6) & $<0,01$ & 22,6 (SD-2,5) & $>0,01$ & 30,1 (SD-1,7) & $>0,01$ & 39,1 (SD-2,6) & $>0,01$ \\
\hline
\end{tabular}

SD: Standard Deviation

Table1: Average of mucous and chloride cells for each group in 7 and 20 days and the statistic results (p) when compared with the control group.

chloride cells proliferated in the Blue Lake group with P greater than 0.01 , in both periods of the experiment.

In the detergent group, such proliferation was observed only after twenty days of exposure, with $\mathrm{P}$ greater than 0.01 . These cells were identified due to their dark-colored granules in the cytoplasm and were located among the secondary lamellae and, in some cases, found in the secondary lamella, according to Pereira and Caetano [9]. As was recorded for the observation of chloride cells, the count of mucous cells with PAS technique showed a proliferation of these cells in all periods of the experiment and in the two groups exposed to pollutants, with $\mathrm{P}$ greater than 0.01 (Table 1 ).

\section{Discussion}

According to Torres and Christofoletti [10] lamellar fusion may have a protective function, because it decreases the gill surface. On the other hand, epithelial hyperplasia, as well as its detachment, might have a defensive function because they increase the distance that substances in the water have to travel to reach the bloodstream.

Therefore, the lamellar fusion found in all groups exposed to pollutants in this experiment demonstrated an attempt of the organism to prevent further absorption of pollutants. Moreover, morphological changes in secondary lamellae were recorded which according to Perry and Laurent [11] can be considered attempts to retain some physiological functions, and may be evidenced by the change in nucleus size in the terminal regions of secondary lamellae. These results were also found by other authors, such as the study of Jiraungkooskul et al. [12], in which proliferation of secondary lamellae cells, hyperplasia, lamellar fusion and aneurysms in gill were the main results obtained after exposure to herbicides.

In addition, the increase in the amount of collagen found in the gills of individuals exposed to detergent may be considered as a modification of the gill structure in order to maintain its integrity and physiological functions, knowing that collagen keep the form of the filament, helping cartilage and bones in gill structure.

According to Perry [3], several studies have suggested that chloride cells are active sites for the regulation of ion transport in marine and freshwater fish, especially in marine fish, in which ion transportation can account for a substantial portion of the energy budget, due to the hydrolysis of ATP by the various ion-transport ATPases (including $\mathrm{Na}^{+} / \mathrm{K}^{+}$-ATPase, high-affinity $\mathrm{Ca}^{2+}$-ATPase and perhaps the poorlydefined $\left.\mathrm{Cl}^{-} / \mathrm{HCO}_{3}-\mathrm{ATPase}\right)$. Under unfavorable ionic conditions or in contact with toxic agents, chloride cells proliferate in the filaments and in the gill lamellar surface [3]. As pointed out by Bindon et al. [13], one of the most often studied and physiologically important morphological adjustments involves significant variation in number and/or size of chloride cells. These findings were confirmed in this experiment which recorded the proliferation of chloride cells, highlighting an attempt of the organisms to regulate ionic imbalance caused by pollutants in the environment.

According to Breseghelo et al. [14], mucous cells in the gill epithelium of fish are responsible for secreting a layer of glycoproteins and glycolipids, which is one of the protection mechanisms of the epithelium. As indicated by Torres and Christofoletti [10], the mucus acts as a barrier, establishing a protective function and it is also important in facilitating ionic regulation. In this study, we identified mucous cells proliferation, whose main function seems to be to establish a protective barrier against the intake of pollutants, which was also confirmed by all the changes recorded. Such proliferation was also reported by Breseghelo et al and Biagini et al. $[14,15]$ in studies using acute exposure to pollutants, as was the case of this work. According to Takashima and Hibiya [16], mucus accumulation on the gill surface may lead to a decrease in gas exchange efficiency. Thus the proliferation observed might be increasing the damage to gill filaments, taking into account the possible decrease in oxygen levels in the cells of gill filaments, which would cause several damages and even lead to cell death.

\section{Conclusion}

From these results we concluded that contaminants contained in the tested polluted environments, such as the urban lake water, generated morphological changes in the fish gills, which might often be considered as attempts of the organism to avoid direct contact with pollutants. However, these changes may weaken the main functions of the gills, such as gas exchange, and lead to ionic imbalance suggested by the proliferation of chloride cells.

\section{Acknowledgments}

The authors are thankful to FAPESP process number: 2009/17118-9 for financial support and to ICMBio/CEPTA - Institute Chico Mendes for providing the specimens used in this experiment.

\section{References}

1. Pough H, Janis CM, Heiser JB (2003) A vida dos vertebrados (3rd edn), São Paulo. Atheneu Publisher, São Paulo Ltda, 700.

2. Machado MR (1999) Uso de brânquias de peixes como indicadores de qualidade das águas. UNOPAR Cient., Ciênc. Biol. Saúde, Londrina 1: 63-76.

3. Perry SF (1997) The Chloride Cell: Structure and Function in the gills of freshwater fishes. Annu Rev Physiol 59: 325-347.

4. Evans DH (2008) Teleost fish osmoregulation: what have we learned since August Krogh, Homer Smith, and Ancel Keys. Am J Physiol Regul Integr Comp Physiol 295: R704-R713.

5. Perry SF, Walsh PJ (1989) Metabolism of isolated fish gill cells: contribution of epithelial chloride cells. J Exp Biol 144: 507-520.

6. Nilsson GE (2007) Gill remodeling in fish - a new fashion or an ancient secret? J Exp Biol 210: 2403-2409.

7. Romão S, Donatti L, Freitas MO, Teixeira J, Kusma J (2006) Blood paramete analysis and morphological alterations as biomarkers on the health of Hoplias malabaricus and Geophagus brasiliensis. Braz arch biol technol 49: 441-448.

8. Roy D (1988) Statistical analysis of anionic detergent-induced changes in the goblet mucous cells of opercular epidermis and gill epithelium of Rita rita (Ham.) (Bagridae: Pisces). Ecotoxicol Environ Saf 15: 260-271.

9. Pereira BF, Caetano FH (2009) Histochemical technique for the detection of chroride cells in fish. Micron 40: 783-786. 
Citation: Pereira BF, da Silva Alves RM, Pitol DL, Senhorini JA, de Alcântara Rocha RCG, et al. (2012) Morphological Gill Analysis of Fish Species Prochilodus Lineatus after Exposure to Pollutants. J Environment Analytic Toxicol 2:130. doi:10.4172/2161-0525.1000130

10. Torres DLFF, Christofoletti CSF (2008) 39 f. Análise de Brânquias de Oreochmis niloticus (Pisces) Residentes em Ambiente Lêntico Impactado. Trabalho de Conclusão de Curso (Graduação em Ciências Biológicas) Instituto de Biociências, Universidade Estadual Paulista "Júlio de Mesquita Filho", Rio Claro.

11. Perry SF, Laurent $P$ (1993) Environmental effects on fish gill structure and fuction 231-264. In: Rnakink JC, Jensen FB. Fish Ecophysiology. Chapman and Hall, London.

12. Jiraungkoorskul W, Upatham ES, Kruatrachue M, Sahaphong S, VichasriGrams S, et al. (2002) Histopathological effects of Roundup, a Glyphosate Herbicide, on Nile tilapia (Oreochromis niloticus). Science Asia 28: 121-127.

13. Bindon SD, Gilmour KM, Fenwick JC, Perry SF (1994) The effects of branchial chloride cell proliferation on respiratory function in the rainbow trout oncorhynchus mykiss. J Exp Biol 197: 47-63.

14. Breseghelo L, Cardoso MP, Borges-De-Oliveira R, da Costa MF, Barreto JCB et al. (2004) Efeitos do fluoreto de sódio no epitélio da brânquia do peixe Guaru (Poecilia vivipara). Braz J Vet Res Anim Sci 41: 274-280.

15. Biagini FR, Fontanetti CS, David JAO (2005) Análise ultramorfológica, histológica e histoquímica de brânquias de Oreochromis niloticus (Tilápia do Nilo) submetidos a águas poluídas tratadas. In: XVII Congresso de Iniciação Científica da UNESP, 17, 2005, Rio Claro. Annals São Paulo: Pró-Reitoria de Pesquisa da Universidade Estadual Paulista "Júlio de Mesquita Filho".

16. Takashima F, Hibiya T (1995) An Atlas of Fish Histology: Normal and Pathological Features.(2ndedn), Tokio: Lubrecht \& Cramer Ltd 213. 